FOLIA POMERANAE UNIVERSITATIS TECHNOLOGIAE STETINENSIS

Folia Pomer. Univ. Technol. Stetin., Oeconomica 2017, 337(88)3, 31-46

Piotr NOWACZYK

\title{
ŹRÓDŁA FINANSOWANIA ROZWOJU MAŁYCH PORTÓW MORSKICH W POLSCE NA PRZYKŁADZIE PORTU W DARŁOWIE
}

\section{FUNDING SOURCES FOR THE DEVELOPMENT OF SMALL SEAPORTS IN POLAND ON THE EXAMPLE OF THE DARŁOWO SEAPORT}

Katedra Marketingu, Zachodniopomorski Uniwersytet Technologiczny w Szczecinie ul. Żołnierska 47, 71-210 Szczecin, e-mail: Piotr.Nowaczyk@zut.edu.pl

\begin{abstract}
Summary. The aim of the article was to identify the sources of funding of port and access infrastructure for the seaport in Darłowo. The Darłowo seaport was a decapitalized object with an inconvenient system of transport connections. After Poland's accession to the EU, an intense process of the port's development began, with the EU funds being the main source of financing. The dominant position of EU funds in the financing structure resulted from the high costs of the port's modernization and the beneficiaries' budget limitations. As a result of the investment process, the fishing infrastructure was modernized and favorable conditions were created for servicing the sailing traffic. The transshipment function of the port - its most promising area of activity - was the most neglected one investment-wise. The main reason behind halting the investment process was the failure to take into account the needs of the port in the state operational programs, which indicates the insufficient engagement of the state into the development of the port. The help of the state in creating infrastructural foundations for the development of transshipment activity is essential for the port's capacity to transform into a specific growth pole, attracting investors and stimulating regional growth.
\end{abstract}

Słowa kluczowe: infrastruktura portowa, port morski, źródła finansowania.

Key words: port infrastructure, seaport sources of funding.

\section{WSTĘP}

Transformacja ustrojowa kraju, zapoczątkowana na przełomie lat 80. i 90. poprzedniego stulecia, objęła gospodarkę morską (Misztal 2010). Małe porty morskie - jako integralny element gospodarki lokalnej - zaczęły przechodzić na własność gmin portowych. W większości przypadków struktury portowe stanowiły obiekty zaniedbane inwestycyjne (Andruszkiewicz 2002; Kowalczyk 2010). Infrastruktura portowa była zdekapitalizowana oraz niekompletna. Dostęp do portów był utrudniony ze względu na ograniczoną przepustowość oraz niekorzystny stan techniczny infrastruktury lądowej i hydrotechnicznej. Rozwój portów morskich wymagał olbrzymich nakładów inwestycyjnych.

Celem artykułu jest wskazanie źródeł finansowania infrastruktury portowej oraz dostępowej portu morskiego w Darłowie. Ze względu na perspektywy rozwoju oraz znaczne zaniedbania inwestycyjne uwagę skupiono na problematyce rozwoju działalności przeładunkowej portu. Z kolei omawiając źródła finansowania, najwięcej miejsca poświęcono możliwościom aplikowania o środki unijne - główne źródło finansowania infrastruktury. Realizacja celu artykułu pozwoli 
odpowiedzieć na pytanie o zakres odpowiedzialności czynnika publicznego za rozwój portu w Darłowie. W artykule sformułowano hipotezę mówiącą, iż państwo wykazuje niewystarczające zainteresowanie rozwojem portu w Darłowie.

Poruszana w artykule problematyka jest aktualna oraz niezmiernie ważna. Proces modernizacji portu darłowskiego nie został zakończony. Ograniczenia w dostępie do źródeł finansowania mogą negatywnie wpływać na możliwości rozwoju portu.

Literatura przedmiotu, dotycząca finansowania rozwoju portów morskich, jest dość obszerna. Jednakże większość opracowań koncentruje się na portach o podstawowym znaczeniu dla gospodarki narodowej. Niniejszy artykuł stanowi próbę zwrócenia uwagi na problematykę finansowania mniejszych struktur portowych.

\section{MATERIA I METODY}

W artykule wyodrębniono zakres rzeczowy, czasowy oraz terytorialny. Zakres rzeczowy obejmuje infrastrukturę portu darłowskiego', tj.: rybacką, przeładunkową oraz rekreacyjno-sportową. Realizacja celu badawczego wymagała uwzględnienia infrastruktury dostępowej do portu, tj. infrastruktury hydrotechnicznej ${ }^{2}$ oraz lądowej ${ }^{3}$, która warunkuje rozwój wszystkich funkcji portu darłowskiego, jednakże dominującą rolę odgrywa w działalności przeładunkowej.

Badania ograniczono do portu w Darłowie. Nie można na podstawie pojedynczego obiektu badawczego formułować uogólniających wniosków na temat całej zbiorowości. Jednak pozostałe małe porty morskie zmagają się z podobnymi problemami (Nowaczyk 2012). Dlatego analiza procesu inwestycyjnego w porcie darłowskim może stanowić cenne źródło informacji o finansowaniu infrastruktury małych portów morskich w Polsce.

Zakres czasowy artykułu obejmuje lata 2004-2016. W rozpatrywanym okresie rozpoczął się intensywny proces rozwoju infrastruktury portowej.

W pierwszym rozdziale przedstawiono czynniki oraz źródła finansowania infrastruktury portów morskich w Unii Europejskiej. W drugim rozdziale zwrócono uwagę na uwarunkowania determinujące finansowanie portu w Darłowie. W dwóch kolejnych rozdziałach skupiono się na charakterystyce oraz ocenie procesu inwestycyjnego realizowanego w porcie darłowskim. W rozdziale piątym dokonano przeglądu programów unijnych pod kątem możliwości ich wykorzystania w finansowaniu małych portów morskich. W ostatnim rozdziale zaproponowano działania umożliwiające dokończenie procesu inwestycyjnego w porcie darłowskim.

W artykule wykorzystano wtórne oraz pierwotne źródła informacji. W tym celu zapoznano się z literaturą przedmiotu oraz z licznymi dokumentami. Przeprowadzono badania $w$ formie ankiety oraz wywiadu pogłębionego, skierowane do przedstawicieli Zarządu Portu Morskiego w Darłowie oraz do użytkowników portu. Na podstawie zebranych materiałów dokonano analizy porównawczej oraz przyczynowo-skutkowej zachodzących zjawisk.

\footnotetext{
1 Do podstawowych składników infrastruktury rybackiej zalicza się nabrzeża oraz baseny rybackie, do infrastruktury przeładunkowej: baseny portowe, nabrzeża portowe oraz drogi dojazdowe; do infrastruktury rekreacyjno-sportowej: przystanie lub/i mariny jachtowe z infrastrukturą towarzyszącą.

2 Infrastruktura hydrotechniczna umożliwia dostęp do portu od strony morza. Zaliczamy do niej: falochrony, tory, kanały oraz baseny portowe.

${ }^{3}$ Infrastruktura lądowa umożliwia dostęp do portu od strony zaplecza, tj. lądowego obszaru oddziaływania portu. Zaliczamy do niej: drogi samochodowe, sieci kolejowe, drogi wodne śródlądowe.
} 


\section{CZYNNIKI ORAZ ŹRÓDŁA FINANSOWANIA INFRASTRUKTURY PORTÓW MORSKICH W UNII EUROPEJSKIEJ}

W państwach Unii Europejskiej (UE) występują znaczne różnice w podejściu do finansowania infrastruktury portów morskich. Zawierają się między dwoma skrajnymi rozwiązaniami, tj. między całkowitą zależnością od środków publicznych oraz pełną samowystarczalnością finansową portów. Zwykle jednak finansowanie infrastruktury ma charakter mieszany, tj. z wykorzystaniem środków publicznych i prywatnych (Pluciński 2017).

Na sytuację finansową portów morskich, a więc i na ich możliwości inwestycyjne wpływa wiele czynników, do których zaliczamy głównie (Misztal 1994; Szwankowski 2000; Grzelakowski i Matczak 2012):

- koncepcję rozwoju gospodarki narodowej,

- presję konkurencji,

- lokalizację,

- rozwój infrastruktury portowej,

- rodzaj infrastruktury,

- system zarządzania portami,

- zakres działalności podmiotów zarządzających portami.

W koncepcji liberalnej, reprezentowanej w UE przez Wielką Brytanie oraz Irlandię, porty traktowane są jako niezależne podmioty gospodarcze. W konsekwencji zarządy portów wykazują niemal całkowitą samowystarczalność finansową i nie otrzymują środków publicznych na rozwój infrastruktury portowej. Natomiast w większości krajów członkowskich (szczególnie Europy kontynentalnej) porty traktowane są jako obiekty użyteczności publicznej - pełniące ważne funkcje gospodarcze, co wynika z przyjętej koncepcji uznania ich za istotne składniki krajowego systemu transportowego. Oznacza to, iż czynnik publiczny sprawuje nadzór nad funkcjonowaniem portów. W związku z tym środki publiczne stanowią ważną pozycję w strukturze wydatków inwestycyjnych.

Większą samowystarczalność finansową mają porty funkcjonujące na monopolistycznym rynku transportowym. Porty na wyspach brytyjskich, porty skandynawskie oraz, w mniejszym stopniu, porty z Półwyspów Apenińskiego i Liberyjskiego pozbawione są konkurencji lądowych środków transportu. Również w sytuacji ograniczonej konkurencji międzyportowej porty wykazują większą niezależność finansową.

Kolejnym czynnikiem wpływającym na strukturę finansowania jest lokalizacja portów. Porty położone bliżej ośrodków konsumpcji i przemysłu oraz w pobliżu większych szlaków komunikacyjnych są atrakcyjniejsze dla użytkowników. Zwiększony popyt na usługi portowe determinuje dochody zarządów portów, co w konsekwencji zwiększa ich możliwości inwestycyjne.

Porty z przestarzałą infrastrukturą portową oraz z niekorzystnym stanem połączeń transportowych znajdują się w gorszej sytuacji konkurencyjnej. Wyrównanie szans rozwojowych, szczególnie w początkowym okresie, przekracza z reguły możliwości budżetowe tych portów. Wymagają one wsparcia z zewnętrznych źródeł finansowania, głównie z budżetu państwa.

W portach UE struktura finansowania portów uzależniona jest od rodzaju infrastruktury. W przypadku infrastruktury umożliwiającej dostęp do portów zarówno od strony morza, jak i lądu obowiązek jej finansowania spoczywa z reguły na czynniku publicznym - państwie. 
Z kolei za utrzymanie i rozwój infrastruktury portowej w większym stopniu odpowiedzialne są podmioty zarządzające portami.

Czynnikiem determinującym sposób finansowania portów, szczególnie infrastruktury portowej, jest przyjęty system zarządzania. W Unii Europejskiej wykształciły się cztery systemy zarządzania portami morskimi: miejski, państwowy, autonomiczny oraz prywatny. W miejskim systemie zarządzania obowiązek finansowania infrastruktury portowej spoczywa na władzach miejskich, a w portach państwowych - na władzach państwowych. Niejednokrotnie samorządy oraz państwo swoje uprawnienia właścicielskie powierzają wyodrębnionym podmiotom, które jednak nadal w znacznym stopniu uzależnione są od pomocy publicznej. W portach autonomicznych zarządzanych przez podmioty w formie spółek handlowych obowiązek rozwoju infrastruktury portowej spoczywa na ich udziałowcach lub akcjonariuszach. Właścicielami portów autonomicznych są z reguły przedstawiciele państwa, samorządu oraz użytkowników portu. Samowystarczalność finansowa portów uzależniona jest od stopnia ich autonomii funkcjonalnej. Zarządy portów mogące angażować się w dochodową działalność usługową wykazują większą niezależność finansową. Tym samym wymagają mniejszego wsparcia zewnętrznego. Z kolei finansowaniem portów prywatnych - szczególnie infrastruktury portowej - zajmuje się sektor prywatny. Funkcjonowanie portów prywatnych opiera się całkowicie na rachunku ekonomicznym. Zarządy portów łączą - na zasadzie wyłączności działalność administracyjno-decyzyjną z działalnością usługową.

Przyjmuje się, że w sytuacji ograniczenia zakresu działalności podmiotów zarządzających portami do zadań administracyjno-zarządczych porty są w stanie wygenerować środki wyłącznie na utrzymanie infrastruktury. Oznacza to, że proces rozwoju portów musi być wspierany ze środków publicznych (Pluciński 2011). Wynika to z charakteru inwestycji infrastrukturalnych, tj. z ich wysokiej kapitałochłonności oraz z niewspółmiernie niskich i rozłożonych w dłuższym okresie dochodów. Finansowanie infrastruktury portowej należy z reguły do przedsięwzięć nieprzynoszących zysku. Brak rentowności finansowej projektów infrastrukturalnych oznacza konieczność ich finansowania ze środków publicznych (Brzozowska 2006). Natomiast w portach, w których za proces inwestycyjny w znacznym stopniu odpowiedzialne są podmioty prywatne ${ }^{4}$ lub w których podmiot zarządzający portami angażuje się w działalność usługową, odnotowuje się większą samowystarczalność finansową.

W ostatnim okresie w państwach UE występuje tendencja do zmniejszania udziału środków publicznych w finansowaniu portów morskich. Jest to spowodowane ograniczeniami budżetowymi państw członkowskich w następstwie kryzysu finansowego oraz wymogami Komisji Europejskiej zalecającej większe zaangażowanie sektora prywatnego w rozwój portów, a tym samym odciążenie budżetów publicznych od kapitałochłonnych nakładów inwestycyjnych (Vanroye i inni 2011). W konsekwencji system finansowania portów morskich ulega przeobrażeniom. Reforma sektora portowego zmierza w kierunku coraz większej samowystarczalności inwestycyjnej zarządów portów. Nadzór publiczny nad portami powierzany jest wyodrębnionym jednostkom gospodarczym, co zwiększa przejrzystość finansowania portów. Podmioty zarządzające portami w większym stopniu angażują się w działalność gospodarczą, tym samym pozyskując dodatkowe źródła dochodów. Przy finansowaniu inwestycji infrastrukturalnych popularne staje się partnerstwo publiczno-prywatne (Bronk 2009).

\footnotetext{
${ }^{4}$ Porty z dominacją sektora prywatnego w sferze usługowej nazywa się często inicjatywą prywatną.
} 
Demonopolizacja działalności usługowej zwiększa aktywność inwestycyjną sektora prywatnego (Grzelakowski i Matczak 2012). Jednakże, pomimo coraz większego urynkowienia działalności usługowej, sektor portowy nadal wspierany jest ze środków publicznych (Pluciński 2017).

\section{UWARUNKOWANIA ROZWOJU PORTU MORSKIEGO W DARŁOWIE}

Głównym aktem prawnym regulującym funkcjonowanie portów morskich w Polsce jest Ustawa z dnia 20 grudnia 1996 r. o portach i przystaniach morskich (ustawa portowa). Zgodnie z jej zapisami porty morskie traktowane są jako obiekty użyteczności publicznej. Znalazło to potwierdzenie w ścisłej kontroli państwa nad obrotem nieruchomościami portowymi oraz w uznaniu infrastruktury za obiekty ogólnodostępne dla użytkowników na warunkach niedyskryminujących. Porty w polskim ustawodawstwie nie są więc traktowane jako podmioty gospodarcze działające na ściśle rynkowych zasadach, jak ma to miejsce w doktrynie liberalnej. Dlatego należałoby się spodziewać znacznego zainteresowania państwa ich rozwojem.

$\mathrm{Na}$ początku pierwszej dekady XXI wieku, a więc przed rozpoczęciem intensywnego procesu inwestycyjnego finansowanego ze środków unijnych, port w Darłowie stanowił strukturę niedoinwestowaną (tab. 1). Infrastruktura portowa była mocno zdekapitalizowana, występowały też braki w jej wyposażeniu. W przypadku infrastruktury hydrotechnicznej wejście do portu wymagało poszerzenia, tor wodny wraz basenami portowymi wymagał pogłębienia, a obrotnica portowa wymagała zwiększenia średnicy. Z kolei stan techniczny dróg był zły, a ich przepustowość była niewystarczająca. Port w Darłowie nie był obsługiwany przez transport kolejowy ze względu na braki infrastrukturalne. Wyżej wymienione ograniczenia uzasadniały zaangażowanie środków publicznych w modernizację infrastruktury portowej.

Tabela 1. Stan techniczny oraz wyposażenie portu morskiego w Darłowie w infrastrukturę portową oraz dostępową w okresie przedinwestycyjnym

\begin{tabular}{|c|c|c|c|c|c|}
\hline \multirow[b]{4}{*}{$\begin{array}{l}\text { Stan } \\
\text { techniczny } \\
\text { infrastruktury } \\
\text { oraz braki } \\
\text { w } \\
\text { wyposażeniu }\end{array}$} & \multicolumn{5}{|c|}{ Infrastruktura } \\
\hline & \multicolumn{3}{|c|}{ portowa } & \multicolumn{2}{|c|}{ dostępowa } \\
\hline & rybacka & przeładunkowa & $\begin{array}{l}\text { rekreacyjno- } \\
\text {-sportowa }\end{array}$ & hydrotechniczna & lądowa \\
\hline & $\begin{array}{l}\text { - zdekapitalizowane } \\
\text { nabrzeża portowe } \\
\text { - niewystarczająca } \\
\text { długość nabrze- } \\
\text { ży portowych } \\
\text { - niewystarczająca } \\
\text { głębokość base- } \\
\text { nów portowych }\end{array}$ & $\begin{array}{l}\text { - zdekapitalizo- } \\
\text { wane nabrzeża } \\
\text { portowe } \\
\text { - niewystarczają } \\
\text { ca długość na- } \\
\text { brzeży }\end{array}$ & $\begin{array}{l}\text { - brak przy- } \\
\text { stani / ma- } \\
\text { riny jach- } \\
\text { towej }\end{array}$ & $\begin{array}{l}\text { - zbyt wąskie } \\
\text { wejście do por- } \\
\text { tu } \\
\text { - za mała głębo- } \\
\text { kość toru wej- } \\
\text { ściowego } \\
\text { - za mała śred- } \\
\text { nica obrotnicy } \\
\text { portowej }\end{array}$ & $\begin{array}{l}\text { - zły stan tech- } \\
\text { niczny oraz } \\
\text { ograniczona } \\
\text { przepusto- } \\
\text { wość infra- } \\
\text { struktury dro- } \\
\text { gowej } \\
\text { - brak połą- } \\
\text { czenia kole- } \\
\text { jowego }\end{array}$ \\
\hline
\end{tabular}

Źródło: opracowano na podstawie przeprowadzonych badań.

Port w Darłowie zaliczany jest do portów lokalnych. Zasięg jego oddziaływania od strony lądu obejmuje otaczające powiaty, choć w przypadku działalności turystycznej wykracza daleko poza granice województwa. Port w Darłowie konkuruje z sąsiadującymi portami lokalnymi, tj. z Kołobrzegiem i Ustką. W przypadku działalności przeładunkowej port konkuruje 
z lądowymi gałęziami transportu oraz - w ograniczonym zakresie - z portami o podstawowym znaczeniu dla gospodarki narodowej. Udział środków publicznych w finansowaniu rozwoju portu - w sytuacji znacznej presji konkurencyjnej, której jest poddawany port w Darłowie staje się koniecznością.

Lokalizacja portu stanowi jego niewątpliwy atut. Port cieszy się dużym zainteresowaniem turystów. W pobliżu znajdują się dwa mniejsze ośrodki miejskie, tj. Koszalin i Słupsk, w dalszej odległości - aglomeracje gdańska oraz szczecińska. W zasięgu przedpola znajdują się porty niemieckie, skandynawskie oraz państw nadbałtyckich. Zaplecze portu ma charakter rolniczo-leśny, co w połączeniu z aktywnością gospodarczą zaplecza, będącą konsekwencją rozpoczęcia licznych inwestycji infrastrukturalnych współfinansowanych ze środków unijnych, takich jak budowa S6 czy farm wiatrowych, zwiększa zapotrzebowanie na usługi portowe. Ograniczeniem są natomiast zmniejszające się od lat zasoby ryb będące w zasięgu jednostek darłowskich rybaków. Dość korzystna lokalizacja Darłowa powinna zwiększać zainteresowanie sektora prywatnego rozwojem portu, tym samym odciążając czynnik publiczny od kapitałochłonnych inwestycji.

Zgodnie z zapisami ustawy portowej podmiotem odpowiedzialnym za utrzymanie i rozwój infrastruktury hydrotechnicznej jest jej właściciel, czyli skarb państwa. W przypadku infrastruktury lądowej (znaczenie w rozwoju działalności przeładunkowej mają zarówno drogi powiatowe, jak i wojewódzkie i krajowe) odpowiedzialność za ich finansowanie spoczywa więc na samorządzie i państwie. Z kolei za utrzymanie i rozwój infrastruktury portowej odpowiedzialna jest gmina miejska Darłowo, która powierzyła swoje uprawnienia właścicielskie Zarządowi Portu Morskiego Darłowo (ZPM) - spółce miejskiej. Z powyższego wynika, iż ustawodawca scedował obowiązki finansowania infrastruktury na czynnik publiczny. Choć w przypadku infrastruktury portowej nie zakazał współuczestniczenia w procesie inwestycyjnym sektorowi prywatnemu.

Port w Darłowie stanowi własność gminy miejskiej i jest zarządzany w systemie miejskim. Stąd odpowiedzialność za jego finansowanie powinna spoczywać na samorządzie. Forma prawna ZPM (spółki prawa handlowego) charakterystyczna dla portów autonomicznych, może zwiększać samowystarczalność portu. Wątpliwe jednak jest to, że podmiot zarządzający portem - szczególnie na etapie modernizacji portu pochłaniającej olbrzymie środki - będzie mógł w pełni uniezależnić się od pomocy miasta.

Ustawodawca ograniczył zakres działalności podmiotu zarządzającego portem, a więc i źródła dochodów, obciążył natomiast kosztami utrzymania i rozwoju infrastruktury portowej. W rezultacie przychody osiągane przez spółkę pokrywają wyłącznie koszty utrzymania portu, nie są jednakże wystarczające do sfinansowania kapitałochłonnych inwestycji infrastrukturalnych (Zieziula i Nowaczyk 2011). Ich realizacją nie jest zainteresowany sektor prywatny ze względu na niską dochodowość lub jej zupełny brak. Stanowi to przesłankę do finansowania rozwoju portu ze środków publicznych. Uzasadnieniem mogą być korzyści ekonomiczne netto dla lokalnej społeczności - nowe miejsca pracy oraz dodatkowe źródła dochodu związane z oddziaływaniem portu na lokalną gospodarkę (Zarzecki 2007). 


\section{CHARAKTERYSTYKA PROCESU INWESTYCYJNEGO REALIZOWANEGO W PORCIE MORSKIM W DARŁOWIE}

W okresie badawczym zrealizowano wiele inwestycji poprawiających funkcjonowanie portu w Darłowie (tab. 2). Wielkość nakładów inwestycyjnych wyniosła 19,4 mln EUR. Głównym źródłem finansowania inwestycji były środki z programów unijnych - 18,2 mln EUR, co stanowiło ponad $93 \%$ całkowitych nakładów inwestycyjnych. Drugim źródłem finansowania były środki komunalne - 1,2 mln EUR, tj. niespełna 7\% wartości zrealizowanych inwestycji.

Tabela 2. Realizacja procesu inwestycyjnego [mln EUR] w porcie morskim w Darłowie w latach 2004-2016

\begin{tabular}{|c|c|c|c|}
\hline \multirow[b]{2}{*}{ Infrastruktura } & \multicolumn{3}{|c|}{ Charakterystyka procesu inwestycyjnego } \\
\hline & nazwa inwestycji & $\begin{array}{c}\text { źródła finansowania oraz } \\
\text { wartość inwestycji [mln EUR] }\end{array}$ & $\begin{array}{c}\text { beneficjenci } \\
\text { inwestycji }\end{array}$ \\
\hline \multirow{5}{*}{ Rybacka } & $\begin{array}{l}\text { modernizacja rybackiej } \\
\text { części portu - etap I }\end{array}$ & SPO „Ryby 2004-2006” $(2,1)$ & gmina Darłowo \\
\hline & $\begin{array}{l}\text { modernizacja rybackiej } \\
\text { części portu - etap II }\end{array}$ & SPO „Ryby 2004-2006” $(0,8)$ & gmina Darłowo \\
\hline & budowa basenu rybackiego & PO „Ryby 2007-2013” (2,6) & gmina Darłowo \\
\hline & $\begin{array}{l}\text { przedłużenie nabrzeża } \\
\text { portowego }\end{array}$ & PO „Ryby 2007-2013” $(1,8)$ & gmina Darłowo \\
\hline & $\begin{array}{l}\text { modernizacja i przebudowa } \\
\text { dwóch nabrzeży we } \\
\text { wschodniej części portu }\end{array}$ & PO „Ryby 2007-2013” (7,3) & $\begin{array}{l}\text { Urząd Morski } \\
\text { w Słupsku }\end{array}$ \\
\hline Przeładunkowa & brak & brak & brak \\
\hline $\begin{array}{l}\text { Rekreacyjno- } \\
\text {-sportowa }\end{array}$ & budowa przystani jachtowej & $\begin{array}{l}\text { PO „IG 2007-2013” }(0,2) \\
\text { gmina Darłowo }(0,1)\end{array}$ & gmina Darłowo \\
\hline Hydrotechniczna & brak & brak & brak \\
\hline Lądowa & $\begin{array}{l}\text { poprawa dostępu do portu } \\
\text { dla transportu } \\
\text { samochodowego }\end{array}$ & $\begin{array}{l}\text { PO „liŚ 2007-2013” }(3,4) \\
\text { gmina Darłowo }(1,1)\end{array}$ & gmina Darłowo \\
\hline
\end{tabular}

SPO „Ryby 2004-2006” (sektorowy program operacyjny „Rybołówstwo i przetwórstwo ryb 2004-2006”); PO „Ryby 2007-2013” (program operacyjny „Zrównoważony rozwój sektora rybołówstwa i nadbrzeżnych obszarów rybackich 2007-2013”); PO „liS 2007-2013” (program operacyjny „Infrastruktura i środowisko 2007-2013”); PO „IG 2007-2013” (program operacyjny „Innowacyjna gospodarka 2007-2013”).

Pięć projektów inwestycyjnych było finansowanych wyłącznie ze środków unijnych. W przypadku dwóch pozostałych wymagany był wkład własny beneficjenta, tj. gminy Darłowo.

Beneficjentem sześciu inwestycji o wartości $12,1 \mathrm{mln}$ EUR (62\% całkowitych nakładów inwestycyjnych) była gmina miejska Darłowo. Drugim beneficjentem był Urząd Morski w Słupsku (UM w Słupsku) - 7,3 mln EUR (38\% ogólnej wartości inwestycji).

Głównym źródłem pozyskiwania środków unijnych były programy operacyjne wspierające restrukturyzację rybołówstwa. Wartość inwestycji rybackich wyniosła 14,6 mln EUR, co stanowiło ponad $80 \%$ środków zaangażowanych w proces inwestycyjny. Pozostałą część, tj. 3,6 mln EUR (niespełna $20 \%$ ), stanowiły środki z krajowych programów operacyjnych.

Najwięcej środków zainwestowano w działalność rybacką - pięć projektów o wartości 14,6 mln EUR, co stanowiło 75\% całkowitych nakładów inwestycyjnych. Jeden projekt o wartości $0,3 \mathrm{mln}$ PLN (2\% nakładów inwestycyjnych) związany był z działalnością 
rekreacyjno-sportową portu. Na poprawę dostępu do portu od strony lądu ${ }^{5}$ przeznaczono 4,5 mln EUR (23\% nakładów inwestycyjnych). Natomiast nie zrealizowano żadnej inwestycji obejmującej infrastrukturę hydrotechniczną oraz przeładunkową.

\section{OCENA PROCESU INWESTYCYJNEGO REALIZOWANEGO W PORCIE MORSKIM W DARŁOWIE}

W rezultacie rozpoczętego procesu inwestycyjnego rybacka część portu została niemal w całości odnowiona; nie wymagała większych nakładów inwestycyjnych. Tymczasem redukcji uległa wielkość floty rybackiej stacjonująca w porcie. W konsekwencji infrastruktura rybacka nie była w pełni wykorzystywana. Jednocześnie nie mogła być przeznaczona do realizacji innych zadań, na które było szczególne zapotrzebowanie w porcie. Zakazywały tego albo warunki, na których zostały pozyskane środki unijne ${ }^{6}$, albo infrastruktura nie była przystosowana od strony technicznej do pełnienia innych funkcji portowych ${ }^{7}$.

Natomiast przystań jachtowa nie posiadała infrastruktury towarzyszącej. Nie zaspokajała więc w pełni potrzeb żeglarzy. Była inwestycją zbyt małą w sytuacji rosnącego ruchu turystycznego i coraz większych wymagań żeglarzy.

Pomijając przebudowę infrastruktury drogowej, w Darłowie nie zrealizowano żadnej inwestycji związanej $z$ działalnością przeładunkową portu. $Z$ tego powodu do portu nadal nie mogły zawijać większe jednostki handlowe. Zły stan techniczny nabrzeży spowalniał obsługę jednostek transportu. Wymienione mankamenty zmniejszały dynamikę wzrostu przeładunków. Najbardziej perspektywiczna funkcja portowa była w największym stopniu niedoinwestowana.

Głównym źródłem finansowania inwestycji infrastrukturalnych, związanych z działalnością portu morskiego w Darłowie, były środki unijne. Wynikało to z kilku przyczyn. Pierwszą z nich były wysokie koszty procesu inwestycyjnego przeprowadzonego w stosunkowo krótkim okresie. Sytuacja finansowa beneficjentów nie pozwalała na realizację inwestycji wyłącznie ze środków własnych. Jedynym podmiotem, który skorzystał z własnych źródeł finansowania, była gmina miejska Darłowo. Jednakże udział środków komunalnych w całkowitych nakładach inwestycyjnych był niewielki. Z pozostałych podmiotów odpowiedzialnych za utrzymanie i rozwój infrastruktury tylko UM w Słupsku zaangażował się w proces inwestycyjny. Pozyskał środki na inwestycję o znacznej wartości, jednakże w całości ze środków unijnych. Ograniczenia budżetowe ZPM Darłowo nie pozwalały na podjęcie procesu inwestycyjnego. Dlatego odpowiedzialność za rozwój portu przejęła gmina.

Drugą przyczyną dominacji środków unijnych w finansowaniu procesu inwestycyjnego były niewspółmiernie małe, w stosunku do nakładów inwestycyjnych, korzyści generowane przez infrastrukturę. W niektórych przypadkach beneficjenci $w$ ogóle nie pobierali opłat od użytkowników infrastruktury ${ }^{8}$. Dlatego w działalność inwestycyjną w porcie zaangażowane były wyłącznie podmioty publiczne ${ }^{9}$.

\footnotetext{
${ }^{5}$ Inwestycja obejmowała przebudowę drogi wojewódzkiej prowadzącej do portu, budowę obwodnicy oraz mostu drogowego.

${ }^{6}$ Programy unijne wspierające rozwój rybołówstwa zakazywały wykorzystywania infrastruktury w innych celach niż związanych z obsługą rybołówstwa.

${ }^{7}$ Nabrzeża rybackie nie mogły być wykorzystywane do przeładunków towarów ze względu na zbyt małe rozmiary oraz parametry wytrzymałościowe.

${ }^{8}$ Przykładem inwestycji niegenerującej dochodu była przebudowa drogi poprawiająca dostęp do portu od strony lądu. Gmina Darłowo ani inny podmiot nie pobiera od użytkowników żadnych opłat za korzystanie z infrastruktury.

${ }^{9}$ W Darłowie niewielka część infrastruktury portowej stanowiła własność podmiotów prywatnych.
} 
Czynnikiem sprzyjającym pozyskiwaniu środków unijnych był ich bezzwrotny charakter oraz w większości przypadków - korzystny poziom współfinansowania inwestycji. Stąd dominacja inwestycji o charakterze rybackim oraz poprawiających jakość infrastruktury drogowej. Mniej korzystne warunki pozyskiwania środków unijnych ograniczyły wielkość nakładów na realizację inwestycji rekreacyjno-sportowych. Z kolei brak możliwości pozyskiwania środków unijnych uniemożliwił unowocześnienie infrastruktury przeładunkowej oraz hydrotechnicznej.

\section{MOŻLIWOŚCI ORAZ WARUNKI POZYSKIWANIA ŚRODKÓW UNIJNYCH NA REALIZACJĘ INWESTYCJI W PORCIE W DARŁOWIE}

Modernizacja portu darłowskiego odbywała się głównie przy współudziale środków unijnych, które determinowały kierunki procesu inwestycyjnego. W okresie badań możliwość finansowania rozwoju infrastruktury portowej oraz dostępowej do portu zakładało wiele programów unijnych (tab. 3).

Tabela 3. Programy unijne wspierające rozwój małych portów morskich w Polsce w latach 2004-2013

\begin{tabular}{|c|c|c|}
\hline \multirow{2}{*}{ Infrastruktura } & \multicolumn{2}{|c|}{ Zakres czasowy } \\
\hline & 2004-2006 & 2007-2013 \\
\hline Rybacka & $\begin{array}{l}\text { SPO „Ryby” } \\
\text { alokacja - } 42 \text { mln EUR } \\
\text { dofinansowanie - } 100 \% \\
\text { infrastruktura rybacka małych portów } \\
\text { i przystani morskich }\end{array}$ & $\begin{array}{l}\text { PO „Ryby” } \\
\text { alokacja - } 144 \text { mln EUR } \\
\text { dofinansowanie - 100\% } \\
\text { infrastruktura rybacka małych portów morskich }\end{array}$ \\
\hline Przeładunkowa & brak & brak \\
\hline $\begin{array}{l}\text { Rekreacyjno- } \\
\text {-sportowa }\end{array}$ & $\begin{array}{l}\text { ZPORR } \\
\text { alokacja - } 10 \mathrm{mln} \text { EUR } \\
\text { dofinansowanie }-85 \% \\
\text { infrastruktura turystyczna małych portów } \\
\text { morskich oraz inne projekty }\end{array}$ & $\begin{array}{l}\text { PO „IG” } \\
\text { alokacja - } 117 \text { mln EUR } \\
\text { dofinansowanie - } 40 \%-60 \% \\
\text { infrastruktura turystyczna o znaczeniu } \\
\text { ponadregionalnym } \\
\text { RPO WZ } \\
\text { alokacja - } 30 \text { mln EUR } \\
\text { dofinansowanie - do } 50 \% \\
\text { infrastruktura turystyczna małych portów } \\
\text { morskich oraz inne projekty }\end{array}$ \\
\hline Hydrotechniczna & brak & $\begin{array}{l}\text { RPO WZ } \\
\text { alokacja - } 9 \text { mln EUR } \\
\text { dofinansowanie }-50 \% \\
\text { infrastruktura hydrotechniczna małych portów } \\
\text { morskich oraz rzecznych } \\
\text { wykluczenie: PO „ISS” oraz PO „Ryby” }\end{array}$ \\
\hline Lądowa & $\begin{array}{l}\text { ZPORR } \\
\text { alokacja - } 35 \text { mln EUR } \\
\text { dofinansowanie }-75 \% \\
\text { infrastruktura drogowa małych portów } \\
\text { morskich oraz inne projekty }\end{array}$ & $\begin{array}{l}\text { PO „liŚ” } \\
\text { alokacja - } 104 \text { mln EUR } \\
\text { dofinansowanie }-85 \% \\
\text { infrastruktura transportowa czterech małych } \\
\text { portów morskich }\end{array}$ \\
\hline
\end{tabular}

Objaśnienie: kolejne wiersze w charakterystyce programów unijnych oznaczają: nazwę programu unijnego, alokację środków na działanie, wielkość dofinansowania, zakres projektów objętych interwencją ew. wykluczenie działania. Źródło: Portal Funduszy Europejskich (http://www.funduszeeuropejskie.2007-2013.gov.pl); Lista projektów indywidualnych dla Programu Operacyjnego Infrastruktura i Środowisko 2007-2013 (https:// www.cupt.gov.pl/ files/CUPT/infrastrukturairodowisko). 
W latach 2004-2006 beneficjenci mogli starać się o środki z sektorowego programu operacyjnego „Rybołówstwo i przetwórstwo ryb 2004-2006” (SPO „Ryby 2004-2006”) oraz ze zintegrowanego programu operacyjnego rozwoju regionalnego (ZPORR). Natomiast w okresie obowiązywania perspektywy finansowej budżetu Unii Europejskiej na lata 2007-2013 beneficjenci mogli ubiegać się o środki z programu operacyjnego „Zrównoważony rozwój sektora rybołówstwa i nadbrzeżnych obszarów rybackich 2007-2013” (PO „Ryby 2007-2013”), z programu operacyjnego „Infrastruktura i środowisko” (PO „liŚ), z programu operacyjnego „Innowacyjna gospodarka” (PO „IG”) oraz z regionalnego programu operacyjnego województwa zachodniopomorskiego (RPO „WZ”).

W programach wspierających restrukturyzację rybołówstwa na unowocześnienie portów rybackich zarezerwowano ponad $186 \mathrm{mln}$ EUR. Była to dość duża kwota, zważywszy na ograniczony krąg beneficjentów, tj. kilkanaście małych portów dysponujących infrastrukturą do obsługi rybołówstwa. Możliwość ubiegania się o całkowite pokrycie wydatków inwestycyjnych dodatkowo zwiększało atrakcyjność programów rybackich. Były to główne przyczyny dominowania w strukturze inwestycyjnej portu darłowskiego projektów o charakterze rybackim.

$\mathrm{Na}$ budowę infrastruktury rekreacyjno-sportowej port w Darłowie mógł pozyskać środki z trzech programów unijnych, tj.: z ZPORR w latach 2004-2006 oraz z PO „IG” i RPO „WZ” w latach 2007-2013. Gmina Darłowo zdecydowała się uczestniczyć w projekcie o nazwie „Zachodniopomorski szlak żeglarski”, finansowanym ze środków PO „IG”. W projekt zaangażowanych było kilkanaście małych portów, co pozwoliło zrealizować inwestycję z programu krajowego. Budowa przystani jachtowej wymagała wkładu własnego beneficjenta, jednakże niewielka wartość inwestycji pozwoliła gminie na jej dofinansowanie. W programie na realizację inwestycji w rozwój infrastruktury turystycznej zarezerwowano znaczne środki, tj. ponad $117 \mathrm{mln}$ EUR, co zwiększało możliwości aplikacyjne. Budowa infrastruktury rekreacyjno-sportowej mogła być również dofinansowana z RPO „WZ”. Jednakże uczestnictwo w projekcie finansowanym z PO „IG” wykluczało możliwość ubiegania się o środki w ramach RPO „WZ”. Z kolei wielkość środków z ZPORR przeznaczonych na realizację projektów turystycznych była mniejsza. Ponadto program przewidywał znacznie szerszy krąg beneficjentów mogących ubiegać się o dofinansowanie.

Programy unijne nie przewidywały środków na modernizację infrastruktury przeładunkowej małych portów morskich. Priorytetem inwestycyjnym były duże porty - o podstawowym znaczeniu dla gospodarki narodowej. W rezultacie infrastruktura przeładunkowa portu nie została zmodernizowana.

W latach 2004-2006 beneficjenci z małych portów morskich mogli starać się o środki unijne na modernizację infrastruktury drogowej. Ze środków ZPORR mogły być finansowane inwestycje o charakterze lokalnym. Natomiast rozwój portu w Darłowie wymagał kompleksowej przebudowy infrastruktury łączącej port z wojewódzką i krajową siecią dróg, a więc przedsięwzięć na znacznie większą skalę. Alokacja środków w ramach ZPORR na poprawę dostępności do małych portów była mniejsza aniżeli w ramach programów rybackich na rozwój infrastruktury rybackiej. Dodatkowo środki rozproszone były na różne działania, w których poprawa dostępności do małych portów była jedną z wielu możliwości inwestycyjnych. Atrakcyjność programu obniżał wymagany wkład własny beneficjentów - na poziomie $25 \%$ wartości inwestycji. Ponadto gmina Darłowo w latach 2004-2006 zaangażowana była w realizację wielu 
projektów inwestycyjnych. Na wspieranie rozwoju działalności przeładunkowej zabrakło środków i czasu. Powyższe okoliczności stanowiły barierę uniemożliwiającą gminie portowej pozyskanie środków z ZPORR. Środki na poprawę dostępności do portu gmina Darłowo otrzymała dopiero z PO „liŚ na lata 2007-2013. Był to tzw. program krajowy, ze środków którego realizowane były inwestycje o większej wartości. W programie zarezerwowana została pula środków wyłącznie dla czterech mniejszych portów morskich. Wśród nich znalazł się port w Darłowie. Na liście projektów podstawowych umieszczona została inwestycja mająca na celu przebudowę drogi wojewódzkiej. Pomimo wymaganego wkładu własnego beneficjenta gminy Darłowo (na poziomie 15\%) inwestycja została zrealizowana.

Programy unijne nie przewidywały natomiast możliwości aplikowania o środki na modernizację infrastruktury kolejowej. W rezultacie port w Darłowie - pomimo zgłaszanego przez operatorów i użytkowników zapotrzebowania - nadal nie był obsługiwany przez transport kolejowy.

W okresie 2007-2013 beneficjenci z małych portów morskich mogli ubiegać się o środki na przebudowę infrastruktury hydrotechnicznej. Możliwości takie stwarzał RPO „WZ”. Jednakże niewielka pula środków zarezerwowana dla małych portów, tj. niespełna $10 \mathrm{mln}$ EUR, pozwalała na zrealizowanie zaledwie kilku projektów. Dodatkową przeszkodę stanowił znaczny wkład własny beneficjenta. Wysoka wartość inwestycji, ograniczenia finansowe oraz mniej korzystne współfinansowanie uniemożliwiły UM w Słupsku - podmiotowi odpowiedzialnemu za utrzymanie i rozbudowę infrastruktury hydrotechnicznej - pozyskanie środków. Barierą były również względy formalne. Ze środków RPO „WZ” nie mogły być finansowane projekty infrastrukturalne kwalifikujące się do objęcia interwencją z innych programów, w tym PO „Ryby 2007-2013” oraz PO „liŚ". Port w Darłowie nie spełniał tego warunku, ponieważ ze środków wymienionych programów były już finansowane projekty inwestycyjne.

Z przeglądu programów unijnych wspierających rozwój działalności przeładunkowej wynika, iż port w Darłowie miał ograniczone możliwości pozyskiwania środków. W rezultacie zmodernizowano wyłącznie infrastrukturę drogową umożliwiającą dostęp do portu. Na realizację inwestycji w rozwój infrastruktury przeładunkowej oraz hydrotechnicznej programy albo nie przewidywały środków albo ze względów formalnych środki nie były możliwe do pozyskania.

\section{MOŻLIWOŚCI DALSZEGO ROZWOJU PORTU MORSKIEGO W DARŁOWIE}

Pomimo znacznych nakładów inwestycyjnych modernizacja portu darłowskiego nie została zakończona. Ze względu na ograniczenia budżetowe beneficjentów należy się spodziewać, iż głównym źródłem finansowania portu w Darłowie nadal bedą środki unijne.

W obecnej perspektywie finansowej UE na lata 2014-2020 podmioty portowe mogą ubiegać się o środki unijne z programu wspierającego restrukturyzację rybołówstwa ${ }^{10}$, gdzie na rozwój małych portów zarezerwowano prawie 269 mln EUR (tab. 4). Część środków zostanie przeznaczona na unowocześnienie infrastruktury rybackiej. W przypadku beneficjentów publicznych program operacyjny przewiduje całkowite pokrycie wydatków inwestycyjnych. Rybacka część portu darłowskiego została zmodernizowana. Nie ma potrzeby dalszej rozbudowy infrastruktury, tym bardziej że liczna grupa rybaków deklaruje chęć odejścia

\footnotetext{
10 Program operacyjny „Rybactwo i morze 2014-2020”.
} 
z zawodu. Ewentualne inwestycje mogłyby dotyczyć przebudowy infrastruktury w celu zagospodarowania przyłowów niechcianych ryb. Nie będą one jednak miały charakteru strategicznego dla portu.

Środki na rozwój infrastruktury rekreacyjno-sportowej zostały zarezerwowane w RPO „WZ”. Wielkość alokacji jest znacznie niższa, aniżeli w poprzednim okresie programowania, ale i potrzeby inwestycyjne w województwie są dużo mniejsze. Przystań jachtowa w Darłowie nie została wyposażona w infrastrukturę towarzyszącą do obsługi jednostek turystycznych. Pojemność przystani - w perspektywie rosnącego ruchu żeglarskiego - może okazać się niewystarczająca. Dlatego infrastruktura turystyczna będzie wymagała uzupełnienia oraz rozbudowy. Środki z RPO „WZ” przewidują partycypację w nakładach inwestycyjnych beneficjentów, ale ze względu na relatywnie niewielką wartość inwestycji, gmina powinna udźwignąć jej ciężar.

Tabela 4. Programy unijne [mln EUR] wspierające rozwój małych portów morskich w Polsce w latach 2014-2020

\begin{tabular}{|c|c|c|c|c|}
\hline \multirow[b]{3}{*}{$\begin{array}{l}\text { Programy } \\
\text { unijne } \\
\text { w latach } \\
2014-2020\end{array}$} & \multicolumn{4}{|c|}{ Infrastruktura } \\
\hline & rybacka & rekreacyjno-sportowa & $\begin{array}{c}\text { przeładunkowa oraz } \\
\text { hydrotechniczna }\end{array}$ & lądowa \\
\hline & $\begin{array}{l}\text { PO „Ryby” } \\
\text { alokacja - } 269 \text { mln EUR } \\
\text { dofinansowanie - do } 100 \% \\
\text { infrastruktura rybacka ma- } \\
\text { łych portów i przystani } \\
\text { morskich oraz inne pro- } \\
\text { jekty }\end{array}$ & $\begin{array}{l}\text { RPO „WZ” } \\
\text { alokacja - } 45 \text { mln EUR } \\
\text { dofinansowanie - do } 85 \% \\
\text { infrastruktura turystyczna } \\
\text { oraz inne rodzaje pro- } \\
\text { jektów }\end{array}$ & $\begin{array}{l}\text { PO „liŚ } \\
\text { alokacja - } 60 \text { mln EUR } \\
\text { dofinansowanie - do } \\
100 \% \\
\text { infrastruktura portowa } \\
\text { oraz hydrotechniczna }\end{array}$ & $\begin{array}{l}\text { RPO „WZ” } \\
\text { alokacja - } 138 \text { mln EUR } \\
\text { dofinansowanie - 85- } \\
-100 \% \\
\text { infrastruktura drogowa } \\
\text { o znaczeniu regionalnym } \\
\text { PO „liS” } \\
\text { alokacja - } 10 \text { mln EUR } \\
\text { dofinansowanie - 85- } \\
\text {-100\% } \\
\text { infrastruktura drogowa } \\
\text { o znaczeniu krajowym }\end{array}$ \\
\hline
\end{tabular}

Objaśnienia zob. tab. 3.

Źródło: Portal Funduszy Europejskich (http://www.funduszeeuropejskie.2007-2013.gov.pl); Ministerstwo Rozwoju. Dokument Implementacyjny do strategii rozwoju transportu (https://www.mr.gov.pl/strony/zadania/fundusze-europejskie/dokument-implementacyjny).

Największe braki inwestycyjne w porcie darłowskim były związane $\mathrm{z}$ działalnością przeładunkową. Beneficjenci zgłaszali potrzebę modernizacji dotychczasowych nabrzeży oraz budowy nowych. Możliwość przyjmowania większych jednostek handlowych, jak już wspomniano, wymagała przebudowy wejścia do portu oraz poszerzenia obrotnicy portowej w przypadku infrastruktury hydrotechnicznej. Środki na wymienione inwestycje przewidują wyłącznie programy krajowe. Początkowo inwestycje zostały uwzględnione i zakwalifikowane do uzyskania dofinansowania w ramach PO „liŚ”. Niestety, prawdopodobnie nie zostaną zrealizowane. Władze państwowe odmowę argumentują ograniczonymi środkami oraz zmianą priorytetów inwestycyjnych - koncentracją funduszy na rozbudowie portów znajdujących się w sieci TEN - T, tj. portów o podstawowym znaczeniu dla gospodarki narodowej.

W roku 2016 rozpoczął się kolejny etap przebudowy drogi wojewódzkiej mającej na celu poprawę dostępności do portu. Inwestycja, której beneficjentem została gmina Darłowo, finansowana jest z RPO „WZ”. Natomiast prawdopodobnie nie dojdzie do realizacji planowanej przebudowy drogi krajowej, której źródłem finansowania miały być środki z PO „liŚ”. Programy 
operacyjne nadal nie przewidują możliwości aplikowania o środki na modernizację infrastruktury kolejowej. Podobnie jak w przypadku infrastruktury przeładunkowej i hydrotechnicznej priorytetem są główne szlaki transportowe.

Nieuwzględnienie w programach krajowych potrzeb inwestycyjnych portu darłowskiego może przyczynić się do stagnacji funkcji przeładunkowej - najbardziej perspektywicznego obszaru działalności portu. Sytuację dodatkowo pogarsza zapowiadane zmniejszenie puli środków dostępnych dla Polski w przyszłym budżecie UE, a więc i zmniejszenie szans na uwzględnienie potrzeb inwestycyjnych portu (Pluciński 2011).

Trudno oczekiwać zaangażowania w rozwój działalności przeładunkowej portu środków pozaunijnych. Infrastruktura przeładunkowa stanowi własność komunalną. Zgodnie z ustawą portową za jej rozwój odpowiedzialna jest gmina wraz z zarządem portu. Jednakże wysoka kapitałochłonność inwestycji, szacowana na kilkanaście mln EUR, przekracza możliwości budżetowe beneficjentów. Dlatego gmina tak wielkie nadzieje pokładała w programach unijnych.

Ze względu na niewielką dochodowość lub nawet jej brak podmioty prywatne nie chcą angażować się w proces inwestycyjny, np. w ramach partnerstwa publiczno-prywatnego. Tendencji tej sprzyja fakt, iż transport morski nie stanowi jedynej drogi wymiany towarowej. Przewoźnicy mają dostęp do coraz lepszej sieci dróg. Dochodowość inwestycji z pewnością podniosłaby perspektywa wzrostu przeładunków, dla osiągnięcia której niezbędna jest jednak poprawa dostępności do portu. Spółki kolejowe - podmioty odpowiedzialne za rozwój infrastruktury i obsługę towarową ${ }^{11}$ przytaczają podobną argumentację jak operatorzy portowi. Niechęć inwestycyjna sektora kolejowego spowodowana jest zbyt małą wielkością przeładunków oraz ich dużą niestabilnością; oba rodzaje infrastruktury - portowa oraz dostępowa do portu wzajemnie się uzupełniają, warunkując rozwój portu.

Za przebudowę infrastruktury hydrotechnicznej oraz lądowej drogi krajowej, tak jak w większości krajów europejskich, odpowiedzialne jest państwo ${ }^{12}$. Inne podmioty, np. miasto Darłowo wraz z ZPM, nie mają możliwości ani środków na realizację wymienionych inwestycji.

Poprawę sytuacji finansowej portu, a więc i możliwości inwestycyjnych można upatrywać w zwiększeniu zakresu działalności ZPM, co wychodziłoby naprzeciw tendencjom występującym w portach Europy Zachodniej. Wymagałoby to jednak zmian ustawowych, co dotychczas spotykało się z oporem władz. Postawa państwa jest niezrozumiała. Z jednej strony władze centralne traktują porty jako obiekty użyteczności publicznej, kontrolując ich funkcjonowanie. Z drugiej strony nie gwarantują ich rozwoju, ograniczając na przykład możliwości pozyskiwania dodatkowych źródeł dochodu.

Reasumując, należy stwierdzić, iż rozwój portu darłowskiego, szczególnie infrastruktury przeładunkowej oraz powiązanej z nią infrastruktury dostępowej, jest uzależniony od większego zainteresowania państwa rozwojem portu. Może to się odbywać poprzez uwzględnienie portu w programach unijnych albo poprzez finansowanie infrastruktury, szczególnie dostępowej, bezpośrednio z budżetu centralnego. Poprawa parametrów infrastrukturalnych z pewnością przyczyni się do zwiększenia wielkości przeładunków, a w konsekwencji do wzrostu zainteresowania portem inwestorów. Port w Darłowie może stać się swoistym biegunem

\footnotetext{
${ }^{11}$ Należą do nich PLK (Polskie Linie Kolejowe) oraz PKP Cargo.

12 Państwo swoje prerogatywy w przypadku infrastruktury drogowej o standardzie krajowej wykonuje za pośrednictwem Generalnej Dyrekcji Dróg Krajowych i Autostrad, a w przypadku infrastruktury hydrotechnicznej za pośrednictwem urzędów morskich.
} 
wzrostu stymulującym rozwój regionalny. Urzeczywistnienie powyższej wizji będzie jednak wymagało, szczególnie w początkowym okresie, pomocy państwa w rozwoju bazy infrastrukturalnej (Wasilewska 2003).

\section{PODSUMOWANIE}

Rozwój portów morskich w Unii Europejskiej finansowany jest zarówno ze środków publicznych, jak i prywatnych. Samowystarczalność portów morskich uzależniona jest od wielu czynników, do których możemy zaliczyć: koncepcję rozwoju gospodarki narodowej, presję wywieraną na porty przez konkurencyjne gałęzie transportu, lokalizację portów, stopień rozwoju oraz rodzaj infrastruktury, przyjęty system zarządzania portami oraz zakres działalności podmiotów zarządzających portami.

Port morski w Darłowie należał do struktur zaniedbanych inwestycyjnie. Infrastruktura portowa była zdekapitalizowana oraz występowały braki w jej wyposażeniu. Dostęp do portu był utrudniony ze względu na niekorzystny stan i niewłaściwe parametry infrastruktury hydrotechnicznej oraz lądowej. Po wejściu kraju do Unii Europejskiej rozpoczął się intensywny proces rozwoju portu. Głównym źródłem finansowania infrastruktury były środki unijne, co wynikało z konieczności poniesienia wysokich nakładów inwestycyjnych oraz występujących ograniczeń budżetowych beneficjentów.

W następstwie podjętego procesu inwestycyjnego infrastruktura rybacka została niemal w pełni unowocześniona. Stworzono dogodne warunki do obsługi ruchu żeglarskiego. Największe braki inwestycyjne związane były z funkcją przeładunkową portu - najbardziej perspektywicznym obszarem działalności portu.

Modernizacja infrastruktury przeładunkowej oraz warunkującej jej rozwój infrastruktury dostępowej nie została uwzględniona w krajowych programach operacyjnych. Gminy morskie, takie jak Darłowo, nie mają z kolei możliwości ani środków do sfinansowania rozwoju małych portów morskich, które dodatkowo muszą konkurować z lądowymi środkami transportu. Zaniechanie procesu inwestycyjnego skazuje port na stagnację i jest wyrazem niewystarczającego zainteresowania państwa jego rozwojem. Jest to sprzeczne z obowiązującą koncepcją traktowania portów morskich jako obiektów użyteczności publicznej. Wyrazem przyjętej doktryny jest ograniczony zakres gospodarczej działalności portów, a więc i możliwości pozyskiwania dodatkowych źródeł dochodów, co wobec wysokiej kapitałochłonności procesu inwestycyjnego powinno uzasadniać nadzór państwa nad rozwojem portów.

Aby port w Darłowie stał się regionalnym biegunem wzrostu, w początkowym etapie rozwoju niezbędna jest pomoc państwa. Dopiero stworzenie infrastrukturalnych podstaw prowadzenia działalności gospodarczej może przyciągnąć do portu inwestorów i umożliwić jego dalszy rozwój.

\section{PIŚMIENNICTWO}

Andruszkiewicz W. 2002. Gospodarka Morska - od centralnego sterowania do gospodarki rynkowej, w: Społeczno-gospodarcze skutki przemian własnościowych i organizacyjnych w gospodarce morskiej. Sytuacja ludzi morza. XVIII Sejmik Morski. Gdańsk, Wydaw. Civitas Christiana, 11-33.

Bronk H. 2009. Modele finansowania infrastruktury transportowej. Finansowanie rozwoju transportu europejskiego. Ekon. Probl. Usług 32, 20. 
Brzozowska K. 2006. Specyfika projektów inwestycyjnych w sektorze publiczny, w: Współczesne problemy zarządzania finansami lokalnymi. Red. A. Kożuch, K. Brzozowska. Kraków, Wydaw. Fundacja Współcz. Zarz., 91-92.

Grzelakowski A.S., Matczak M. 2012. Współczesne porty morskie - funkcjonowanie i rozwój. Gdynia, Wydaw. Akad. Mor., 130-141.

Kowalczyk U. 2010. Porty lokalne w strategii rozwoju miast i gmin nadmorskich, w: Polska gospodarka morska. Red. H. Salmonowicz. Szczecin, Wydaw. Kreos, 293.

Lista projektów indywidualnych dla Programu Operacyjnego Infrastruktura i Środowisko 2007-2013, https://www.cupt.gov.pl/files/CUPT/infrastrukturairodowisko/2015.02.09\%20Lista\%20projektow\%20 indywidualnych\%20dla\%20POliS.pdf, dostęp: 23.04.2017.

Ministerstwo Rozwoju. Dokument implementacyjny do strategii rozwoju transportu, https://www.mr.gov.pl/ /strony/zadania/fundusze-europejskie/dokument-implementacyjny, dostęp: 25.04.2017.

Misztal K. 1994. Porty morskie w Unii Europejskiej. Gdańsk, Wydaw. UGdań., 25-28.

Misztal K. 2010. Organizacja i funkcjonowanie portów morskich. Gdańsk, Wydaw. UGdań., 263.

Nowaczyk P. 2012. Finansowanie małych portów morskich w Polsce w dobie kryzysu gospodarczego, w: Gospodarka XXI wieku. Red. A. Fudali. Szczecin, Wydaw. Nauk. IVG, 51-65.

Nowaczyk P. 2015. Małe porty morskie w strategiach rozwoju gmin nadmorskich. Przedsiębiorczość i zarządzanie. Strategia jednostki samorządu terytorialnego w świetle wyzwań XXI wieku. Cz. 1. Zesz. SAN Łódź 16(4), 5-72.

Pluciński M. 2011. Zasady i źródła finansowanie inwestycji infrastrukturalnych w polskich portach morskich - stan obecny, kierunki ewolucji. Logistyka 3(11), 2196-2197.

Pluciński M. 2017. Pomoc publiczna w realizacji inwestycji infrastrukturalnych w portach morskich. Przykład portu w Szczecinie. Probl. Transp. Log. 1(37), 259-264.

Portal Funduszy Europejskich, http://www.funduszeeuropejskie.2007-2013.gov.pl/Organizacja Funduszy Europejskich/, dostęp: 20.04.2017.

Szwankowski S. 2000. Funkcjonowanie i rozwój portów morskich. Gdańsk, Wydaw. UGdań., 133.

Ustawa z dnia 20 grudnia 1996 r. o portach i przystaniach morskich. DzU z 1997 r., nr 9, poz. 44, z późn. zm.

Vanroye K., Verweij K., Kort R., Koster M. de, Kramer H., Meyer G., Dubreuil D., Deffontaines G. 2011. Pomoc państwa dla portów morskich w UE. Bruksela, Parlament Europejski, 5-8.

Wasilewska K. 2003. Polityka rozwoju portów morskich a polityka regionalna, w: Ekonomika portów morskich i polityka portowa. Red. L. Kuźma. Gdańsk, Wydaw. UGdań., 248-255.

Zarzecki D. 2007. Wybrane elementy analizy finansowej inwestycji portowych na Ostrowie Grabowskim. Ekon. Probl. Usług 7, 84-85.

Zieziula J., Nowaczyk P. 2011. Zmiana profilu działalności małych portów morskich w Polsce a procesy dostosowawcze w zakresie infrastruktury. Probl. Transp. Turyst., Zesz. Mor. 5(1), 247-264.

Streszczenie. Celem artykułu było wskazanie źródeł finansowania infrastruktury portowej oraz dostępowej portu morskiego w Darłowie. Port w Darłowie stanowił obiekt zdekapitalizowany, z niekorzystnym systemem połączeń transportowych. Po wejściu kraju do Unii Europejskiej rozpoczął się intensywny proces rozwoju portu, którego głównym źródłem finansowania były fundusze unijne. Dominacja środków unijnych w strukturze finansowania wynikała $z$ wysokich kosztów modernizacji portu przy ograniczeniach budżetowych beneficjentów. W efekcie podjętego procesu inwestycyjnego zmodernizowano infrastrukturę rybacką oraz stworzono dogodne warunki do obsługi ruchu żeglarskiego. Największe zaniechania inwestycyjne związane były z funkcją przeładunkową - najbardziej perspektywicznym obszarem działalności portu. Główną przyczyną wstrzymania procesu inwestycyjnego było nieuwzględnienie potrzeb portu w krajowych programach operacyjnych, co świadczy o niewystarczającym zainteresowaniu państwa rozwojem portu. Pomoc państwa w tworzeniu infrastrukturalnych podstaw rozwoju działalności przeładunkowej jest niezbędna, aby port mógł przyciągać inwestorów i stymulować rozwój regionalny. 
